\title{
PEMIKIRAN EKONOMI ISLAM KONTEMPORER
}

Oleh

Devita Ayu Fildayanti//90100118020

email: devita29.akt@gmail.com

Dalam pemikiran ekonomi Islam kontemporer, terdapat kesepakatan di antara para pemikir tentang landasan filosofis dasar bagi sistem ekonomi Islam. Tauhid (keesaan Tuhan), ibadah, khilafah (kekhalifahan), dan takaful (kerja sama) sebagai pilar-pilar filosofis sistem ekonomi Islam. Demikian pula tidak terdapat perbedaan pendapat mengenai hal-hal yang secara jelas disebut dalam al-Quran dan Sunnah, seperti kewajiban membayar zakat dan pelarangan riba di dalam sistem ekonomi islam (Hamzah et al., 2020). Pemikiran ekonomi islam kontemporer dapat dikategorikan dalam tiga kelompok mazhab pemikiran sebagai berikut.

\section{Mazhab Baqr As-Sadr}

Ide dasar yang pertama dari mazhab Baqr As-Sadr adalah terdapat perbedaan yang mendasar antara islam dengan ilmu ekonomi, keduanya merupakan sesuatu yang berbeda. Islam adalah islam sedangkan ilmu ekonomi adalah ilmu ekonomi, tidak ada yang disebut ekonomi islam. Menurut mazhab ini dalam Islam tidak mengenal konsep sumber daya ekonomi yang terbatas, alam semesta ini maha luas. Jika manusia bisa memanfaatkannya niscaya tidak akan pernah habis (Amaroddin, 2018).

\section{Mazhab Mainstream}

Pemikiran ekonomi Islam dari mazhab mainstream inilah yang paling banyak memberikan warna dalam wacana ilmu ekonomi Islam sekarang karena kebanyakan tokoh-tokohnya dari Islamic Development Bank (IDB) yang memiliki fasilitas dana dan jaringan kerja sama dengan berbagai lembaga internasional. Menurut mazhab mainstream bahwa memang secara keseluruhan tidak terjadi kesenjangan antara jumlah sumber daya ekonomi dengan kebutuhan manusia artinya ada keseimbangan (equilibrium). Namun secara relatif pada satu waktu tertentu dan pada tempat tertentu tetap akan dijumpai persoalan kelangkaan tersebut (Khoir, 2010).

\section{Mazhab Alternatif Kritis}

Mengkritik mazhab-mazhab sebelumnya. Madzhab Baqr dikritik sebagai mazhab yang ingin menemukan sesuatu yang sudah ada dan sudah ditemukan oleh orang lain, bahkan sudah diamalkan oleh orang lain. Mazhab mainstream dikritik karena 
merupakan jiplakan dari konvensional yang menghilangkan riba kemudian mengganti dengan zakat dan niat. Menurutnya analisis kritis bukan saja terhadap sosialisme dan kapitalisme tetapi juga pada konsep ekonomi Islam. Diyakini bahwa Islam pasti benar, tetapi ekonomi Islam sebagai sebuah tafsir terhadap ajaran Islam belum tentu benar, dan seandainya benar maka kebenaran itu tidak bersifat mutlak (Abidin, 2014).

\section{TOKOH PEMIKIR EKONOMI ISLAM KONTEMPORR}

\section{Muhammad Abdul Mannan}

Muhammad Abdul Mannan lahir di Bangladesh tahun 1938. Asumsi dasar Muhammad Abdul Mannan membahas sifat, ciri dan kerangka institusional ekonomi Islam yaitu pertama, kerangka sosial islam dan hubungan yang terpadu antara individu, masyarakat, dan negara. Kedua, kepemilikan swasta yang relatif dan kondisional. Ketiga, mekanisme pasar didukung oleh kontrol, pengawasan dan kerja sama dengan perusahaan negara terbatas. Keempat, implementasi zakat dan penghapusan bunga atau riba (Santoso, 2016).

\section{Syed Nawab Haedir Naqvi}

Naqvi lebih melihat kegiatan ekonomi sebagai sebuah aspek budaya yang muncul dari pandangan dunia seseorang. Naqvi membangun konsep bahwa nilai-nilai material tunduk kepada nilai-nilai yang ditetapkan oleh Tuhan dan diajarkan oleh para Nabi dan Rasulnya. Ada dua hal penting dalam pendekatan umum yang digunakan. Pertama, adalah penerimaannya terhadap teori dan alat-alat analisisnya. Pendekatan yang kedua, adalah bahwa ekonomi Islam itu merupakan suatu agen Islamisasi (Yusup, 2014).

\section{Monzer Kahf}

Monzer Kahf melihat ekonomi dalam suatu sistem ekonomi Islam tidak dari sudut pandang afiliasi keagamaan, melainkan sebagai agen yang bersedia menerima paradigma Islam. Kahf juga menyebutkan fungsi Negara dalam perencanaan maupun Negara sebagai produsen (bagi barang-barang publik) dan konsumen. Sesuai dengan landasan atau pilar sistem ekonomi Islam, individu maupun Negara menerima 'rules of the game' yang menurut Kahf menjunjung tinggi nilai kesamaan, persaudaraan, tanggung jawab, akuntabilitas, penuh semangat, perbaikan, perdamaian, dan kerja sama (Ulum, 2013). 


\section{DAFTAR PUSTAKA}

Abidin, Zainal. (2014). Mapping Pemikiran Akademisi dalam Madzhab Ekonomi Islam Kontemporer. Iqtishadia. 1(2), 263-274.

Amaroddin, Muchamat. (2018). Konstruksi Sistem Ekonomi Islam Pemikiran Tokoh Ekonomi Islam Kontemporer. 5(1), 41-55.

Hamzah, Ali \& Mhd. Rasyidin. (2020). Pemikiran Ekonomi Islam Kontemporer: Kajian Teoritis Muhammad Abdul Mannan Tentang Distribusi. Al-Qisthu: Jurnal Kajian Ilmu-ilmu Hukum.18(1), 22-28.

Khoir, Misbahul. (2010). Pemikiran dan Mazhab Ekonomi Islam Kontemporer. Balance Economics, Bussiness, Management and Accounting Journal. VII(12), 15-26.

Santoso, Sugeng. (2016). Sejarah Ekonomi Islam Masa Kontemporer. AN-NISBAH. 03(01), 64 .

Ulum, Fahrur. (2013). Laporan Penelitian: Dinamika Konstruksi Sistem Ekonomi Islam (Studi Komparasi Pola Pemikiran Beberapa Tokoh Ekonomi Islam Kontemporer. $0-25$.

Yusup, Asdar. (2014). Paradigma Kontemporer Ekonomi Islam (Muh. Abdul Mannan versus Syed Nawab Haedir Naqvi). Hunafa: Jurnal Studia Islamika. 11(2), 215244. 